1960-61. He lectured at the National Universities of Trujillo, Cuzco, and Arequipa.

Richard E. Neustadt continued through the spring term to serve in Washington as advisor to President Kennedy on government organization.

James R. Roach of the government department at the University of Texas has been appointed Fulbright lecturer in political science at Rajasthan University, Jaipur, India, for the 1961-62 academic year.

Robert Scigliano, associate professor of political science at Michigan State University has been awarded Rockefeller and Ford grants to conduct research in political development in Vietnam.

Kurt Shell, currently assistant professor at Harpur College, has accepted an invitation from the Free University of Berlin to undertake a research project on the 1962 Berlin elections and to lecture on comparative politics.

Frank J. Sorauf, associate professor of political science, Pennsylvania State University was visiting associate professor, department of government, University of Arizona for the 1960-61 academic year, replacing Professor Bernard Hennessy who is on special leave as associate director of the Citizenship Clearing House.

Arnold S. Trebach, assistant professor of political science, University of Tennessee went on leave and joined the staff of the United States Commission on Civil Rights on July 25, 1960. He was promoted to chief of the Administration of Justice Section of the Commission on August 15, 1960 , and is currently directing the study of discrimination in the operation of police agencies and of the courts in the United States.

Paul W. van der Veur, University of Hawaii, has been granted a two-year leave to serve as a senior research fellow in the New Guinea Research Unit of the Australian National University at Canberra. He will be engaged in library and field research on the political development of Australian and Netherlands New Guinea.

Manfred C. Vernon of the University of Alabama is on leave of absence during the current academic year and is serving as a Fulbright Fellow at the University of Ankara, Ankara, Turkey.

Joseph Zimmerman of Worcester Polytechnic Institute has been elected president of the Citizen's Plan E Association. He is also consultar.t for the Massachusetts Commission on Atomic Energy.

For inclusion in a special report to be published in Labor History, anyone doing research in the field of American labor history is asked to write to Professor Albert A. Blum, Labor and Industrial Relations Center, Michigan State University, East Lansing, Michigan, giving his name, organizational association, and tentative title of the study as well as a brief description of it.

The Institute for American Universities in Aixen-Provence has a rotating lectureship in International Relations, to which American university faculty members are invited annually. The appointment and modest stipend may be of interest to faculty members on sabbatical leave, on research grants or in retirement. Aix-en-Provence has good research facilities and the Institute is developing an active program of Contemporary European Studies. Further information concerning the Institute and prior visiting lecturers may be found in the Institute's catalogue, which is available in most university libraries or by writing directly to the Director, at 21 rue Gaston de Saporta, Aix-en-Provence.

\title{
APPOINTMENT AND STAFF CHANGES
}

Richard Bardolph has been made chairman of the political science department at the Woman's College of the University of North Carolina.

A. Doak Barnett of the Ford Foundation has accepted an appointment as associate professor of government at Columbia University and member of the staff of the East Asian Institute, with responsibility for work on the politics of contemporary China.

Willard A. Beling, formerly of Harvard University, has been appointed professor of international relations at the University of Southern California.

Eliot S. Berkley, formerly dean of administration at the Kansas City Art Institute and School of Design, has been appointed vice-president for development.

David A. Booth, has joined the department of political science at Michigan State University as an assistant professor.

P. Allan Dionisopoulos of Indiana University accepted an appointment, effective September 1, 1960, as assistant professor, department of government, University of Arizona.

JeDon Emenhiser, who has served this past year as instructor in political science at the Redlands University, has accepted an appointment for 1960-61 at Utah State University as instructor in political science.

Henry W. Ehrmann, formerly of the University of Colorado, has been appointed professor of government at Dartmouth College.

George Fischer, formerly of Brandeis University, has been appointed research associate of the center for international studies, Massachusetts Institute of Technology. 
After teaching two and a half years at Hunter College, Robert Fried was appointed assistant professor of government at Bard College. He began his new duties in February.

Robert Giles (Chicago, Ph.D. '52) last on the staff of South Texas College, was appointed lecturer in the school of government and public administration and lecturer in the department of history, College of Arts and Sciences, of American University in the fall semester, 1960.

Stewart L. Grow, formerly chairman of the department of political science, Brigham Young University, has been appointed director of the institute of government service. He is now on leave from teaching duties to work on the organization and curriculum for the new institute. Mark Cannon, formerly assistant to Congressman H. A. Dixon of Utah, has been appointed chairman of the political science department.

William J. Keefe of Chatham College has been promoted to professor of political science.

Earl O. Kline who recently received his Ph.D. from Princeton University, has been promoted to associate professor of political science at The Citadel.

Martin Lichterman has resigned from the Massachusetts Institute of Technology in order to take up new duties on February 1 as executive secretary of the New England Board of Higher Education in Winchester, Massachusetts. Dr. Lichterman had been on leave of absence from M.I.T. since February, 1959, in order to serve as research director in the office of the Governor of the Commonwealth of Massachusetts.

Gerard J. Mangone has been appointed executive officer of the new Maxwell Center for the Study of Overseas Operations at Syracuse University. He recently completed a trip to Nigeria, India, Pakistan, Hong Kong, and Japan where the Maxwell School either has or contemplates overseas programs.

Harry A. Marlow has been appointed assistant professor at the graduate school of public and international affairs.

Alfred G. Meyer was promoted to professor of political science at Michigan State University last summer. He was one of two American professors participating at the centennial celebration of the A. I. Cuza University in IASI, Rumania in October-November.

Daniel P. Moynihan, formerly director of the New York State Government Research Project at Syracuse University has been appointed assistant professor of political science at the Max- well School.

Lowell G. Noonan has resigned as associate professor of political science at the University of Southern California to become associate professor of political science at San Fernando Valley State College in Northridge, California.

Joseph L. Nyomarkay, formerly of the University of Minnesota, has been appointed an instructor in the department of political science at the University of Southern California.

Arthur L. Peterson has joined the faculty at Ohio Wesleyan University as director of the Arneson Institute of Practical Politics and lecturer in political science. Mr. Peterson was most recently attached to the Republican National Committee as a fellow under the Citizenship Clearing House Program.

Claude S. Phillips, Jr., associate professor of political science, has been named director of the newly created institute of regional studies at Western Michigan University. The institute has been set up to improve teaching and offerings on the Non-Western World under a Carnegie grant.

Sam Pearce Pinkerton has been appointed professor of political and social science in the military, United States and world affairs department of the U. S. Army Information School.

Joseph Pois, financial vice president and director of the Signode Steel Strapping Company has been named professor of public administration and director of the public administration program of the graduate school of public and international affairs at the University of Pittsburgh.

Wendell G. Schaeffer, associate professor of public affairs has been nomed assistant dean of the graduate school of public and international affairs, University of Pittsburgh.

Malcolm Smith, who has been a consultant for the U. S. Civil Rights Commission, has been appointed professor of government and acting assistant director of the governmental research bureau at the State University of South Dakota.

Helen Shirley Thomas has been promoted to assistant professor in political science at Goucher College.

Eric Voegelin of the Institut Für Politische Wissensehaften, University of Munich, has also accepted appointment to the permanent faculty of the University of Notre Dame.

Warren Weston, formerly at New Mexico Highlands University has been appointed assistant professor of political science at the University of Denver.

\section{IN MEMORIAM}

Luther J. Lee, Jr., former dean of the Claremont Graduate School and for fifteen years a valued member of the department of govern- ment at Pomona College, died March 31 at his home in Claremont after a year's illness with lateral sclerosis. He was 49 . 